\title{
The frequency of calcium and magnesium differences in recirculation systems for increasing production of mudcrab Scylla serrata seed
}

\section{Frekuensi penambahan kalsium dan magnesium yang berbeda pada sistem resirkulasi untuk meningkatkan produksi budidaya benih kepiting bakau Scylla serrata}

\author{
Wildan Nurussalam, Kukuh Nirmala*, Eddy Supriyono, Yuni Puji Hastuti \\ Department of Aquaculture, Faculty of Fisheries and Marine Science, Bogor Agricultural University \\ Campus IPB Dramaga Bogor, West Java, Indonesia 16680 \\ *E-mail: kukuhnirmala@yahoo.com
}

\begin{abstract}
Molting phase is one of many factors that can inhibit mudcrab growth. Recirculation system in culturing mudcrab has a weakness which is the decreasing of ions. Calcium and magnesium in the water can affect the molting phase. The aim of this study was to evaluate the best additional frequency of calcium and magnesium in recirculation system. This research used mudcrab seeds that have weight of 54.856 \pm 2.195 gram. This research used completely randomized design with four treatments and three replicates. The treatments were additional frequency of $\mathrm{Ca}$ and $\mathrm{Mg}$, comprised of four levels, without additional $\mathrm{Ca}$ and $\mathrm{Mg}(\mathrm{A})$, additional $30 \mathrm{mg} / \mathrm{L} \mathrm{Ca}$ and $30 \mathrm{mg} / \mathrm{L} \mathrm{Mg}$ in every five days (B), additional $30 \mathrm{mg} / \mathrm{L} \mathrm{Ca}$, and $30 \mathrm{mg} / \mathrm{L} \mathrm{Mg}$ in every 10 days (C), and additional $30 \mathrm{mg} / \mathrm{L} \mathrm{Ca}$ and 30 $\mathrm{mg} / \mathrm{L} \mathrm{Mg}$ in every 15 days (D). The result showed that total of biomass in every treatments were A $(379.99 \pm 86.16$ gram), B (517.65 \pm 103.94 gram), C (808.68 \pm 59.29 gram), and D (1,054.41 \pm 73.54 gram). The highest final biomass was the $\mathrm{D}$ treatment $(1,054.41 \pm 73.54)$, which was significantly different to others $(\mathrm{P}<0.05)$.
\end{abstract}

Keywords: mudcrab, resirculation, calcium, magnesium, molting, production

\begin{abstract}
ABSTRAK
Salah satu faktor penghambat pertumbuhan kepiting bakau adalah fase molting. Sistem resirkulasi budidaya kepiting bakau memiliki kelemahan yaitu berkurangnya ion-ion. Fase moting pada kepiting bakau sangat dipengaruhi oleh keberadaan ion kalsium dan magnesium dalam air. Penelitian ini bertujuan untuk menentukan frekuensi waktu penambahan kalsium dan magnesium terbaik dalam sistem resirkulasi. Penelitian ini menggunakan benih kepiting bakau dengan berat rata-rata 54,856 $\pm 2,195$ gram. Penelitian ini menggunakan rancangan acak lengkap (RAL) dengan empat perlakuan dan tiga ulangan. Perlakuan penambahan Ca dan $\mathrm{Mg}$ sebanyak $30 \mathrm{mg} / \mathrm{L}$ terdiri atas empat macam frekuensi, yaitu tanpa penambahan Ca dan $\mathrm{Mg}$ (A), frekuensi lima hari sekali (B), frekuensi 10 hari sekali (C), dan frekuensi 15 hari sekali (D). Hasil penelitian menunjukkan jumlah biomassa masing-masing perlakuan adalah A (379,99 $\pm 86,16$ gram), B (517,65 $\pm 103,94$ gram), C (808,68 $\pm 59,29$ gram), dan D (1.054,41 $\pm 73,54$ gram). Perlakuan terbaik diperoleh pada perlakuan D dengan jumlah biomassa sebesar $(1.054,41 \pm 73,54$ gram $)$ ini berbeda nyata $(\mathrm{P}<0,05)$ dengan perlakuan lainnya.
\end{abstract}

Kata kunci: kepiting bakau, resirkulasi, kalsium, magnesium, molting, produksi

\section{INTRODUCTION}

The consumer of mud crab Scylla serrata is still dominated by the upper middle class society. The culture process of mud crab currently is only located in the area that is near with the source of sea water. Recirculation system is an altenative technology in aquaculture that can provide opportunities for urban people to conduct the culture of mud crab due to its potential to minimize the use of sea water that is costly to be supplied to urban areas. This technology can also applied by the farmers in coastal areas to reduce the water replacement during the farming 
process. Recirculation system is a circulation system of water, draining water from rearing containers to filter (treatment) containers, then drained back to rearing containers (Timmons \& Losordo, 1994). This system is applied in the fish farming under the controlled environmental conditions. Recirculation system is a method in aquaculture that does not depend on the time and seasons (Shannon et al., 2008). However, recirculation system also had a disadvantage that is the reduction of ions contained in the water during the rearing process. This is caused by the absorption of ions by organisms that live in the water to support their growth.

One of ions that is reduced in large quantities in recirculation system is calcium. This occurs because calcium is used by crabs for the formation of carapace. Carapace is the largest part of the crab body. The high requirement of calcium in crabs cultured in recirculation system cannot be fulfilled only from the environment where crabs live and the feed. It needs an addition from an external source to add the amount of calcium contained in the environment. Calcium is important for the formation of bones and exoskeleton of crustacea. Calcium is an essential mineral that is requred in a high amount (Teruaki et al., 2009). In crustacea experiencing postmolt phase, the shell hardening occurs through the deposition of calcium in the shell. Calcium derived from the environment is very dominant in the hardening process of the shell of crustacea (Granado, 2010).

Calcium is required by crustacea in the shell formation phase. In normal condition, the calcium content of crab is $10.75 \mathrm{~g} / 100 \mathrm{~g}$ while in the shell formation phase the calcium content increases to be $29.14 \mathrm{~g} / 100 \mathrm{~g}$ (Marzuki et al., 2013). Magnesium contained in the body is able to increase the absorption of calcium (Fabritius et al., 2012). Due to this relationship between calcium and magnesium, so magnesium is also used to increase the absorption of calcium during the mud crab shell formation phase. The molting period in the cultured crab juveniles has not been known, and the molting times are also not simultaneous. In this study, the different frequencies of the addition of calcium and magnesium were applied, so when crabs molted, calcium contained in the water is on an adequate amount.

This study aimed to determine the optimum frequency of the addition of calcium and magnesium in recirculation system to increase the production and the shell formation of mud crab.

\section{MATERIALS AND METHODS}

\section{Animals and experimental design}

Animals used in this study were 120 mud crabs with an average weight of $54.856 \pm 2.195 \mathrm{~g}$ derived from a collecting farmer in Demak, Central Java. Each experimental tank was stocked with 10 mud crabs reared in recirculation system (Figure 1). The sources of calcium and magnesium used in this study were origined from $\mathrm{CaO}$ (calcium oxyde) and $\mathrm{MgSO}_{4}$ (magnesium sulfate).

This study was conducted through completely randomized design (CDR) consisting of four treatments and three replicates for each treatment. Treatments applied consisted of: A (without the addition of $\mathrm{Ca}$ and $\mathrm{Mg}), \mathrm{B}(30 \mathrm{mg} / \mathrm{L} \mathrm{Ca}$ and 30 $\mathrm{mg} / \mathrm{L} \mathrm{Mg}$ added every five days), $\mathrm{C}$ (30 mg/L Ca and $30 \mathrm{mg} / \mathrm{L} \mathrm{Mg}$ added every 10 days), and D (30 $\mathrm{mg} / \mathrm{L} \mathrm{Ca}$ and $30 \mathrm{mg} / \mathrm{L} \mathrm{Mg}$ added every 15 days).

\section{Experimental parameters}

In this study, several parameters were tested including the amount of calcium and magnesium, dynamics of water quality, physiological response, and production parameters.

Parameters indicating the amount of calcium and magnesium consisted of: the calcium content in the water, the calcium content in the crab body, the magnesium content in the water, the magnesium content in the crab body, the amount of calcium in the feed, and the amount

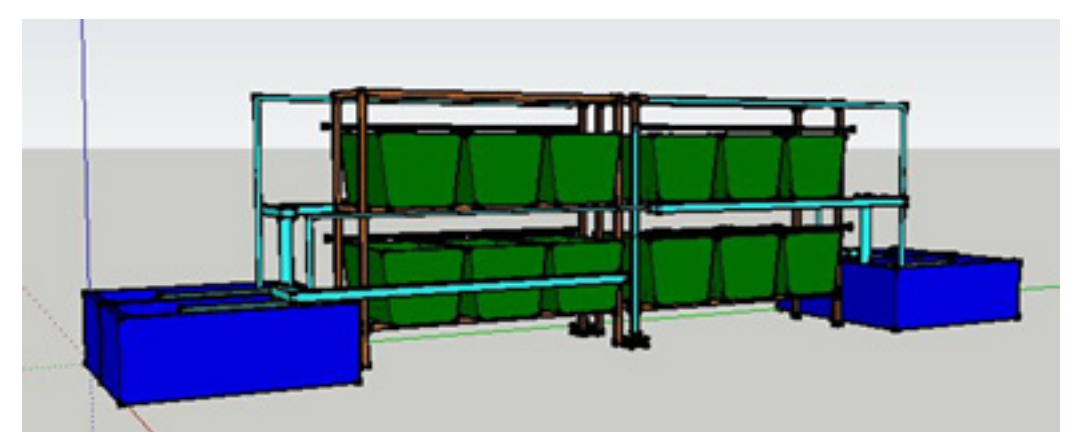

Figure 1. Recirculation system applied in this study. 
of magnesium in the feed. The measurements of these parameters were performed at the beginning and the end of the rearing period. The measurement technique used atomic absorption spectrophotometer (AAS) (Marzuki et al., 2013).

Water quality parameters: daily and weekly water quality parameters. Daily water quality parameters included: temperature, dissolved oxygen and water $\mathrm{pH}$, the measurement used tools which could directly measured those parameters in-situ (APHA, 2012). Weekly water quality parameters included: ammonia, nitrite, nitrate, alkalinity, and salinity. The measurement used titration method or used spectrophotometer (APHA, 2012).

Osmotic gradient measured using osmometer (The formula of osmotic gradient $=$ [the crab hemolymph osmolarity $\left(\mathrm{mOsm} / \mathrm{L} \mathrm{H}_{2} \mathrm{O}\right)$ - the medium osmolarity $\left(\mathrm{mOsm} / \mathrm{L} \mathrm{H}_{2} \mathrm{O}\right)$ ].

Production parameters: feed conversion ratio, daily growth rate, the number of molting, survival, and total biomass (NRC, 1977). The calculation was conducted at the end of the study based on the results of sampling conducted every seven days.

\section{Statistical analysis}

Data obtained were tabulated and were analyzed using Microsoft Excel 2013 and SPSS 17.0. Data obtained were presented in table, chart, or figure. Data were analyzed through analysis of variance (ANOVA) with $\mathrm{F}$ test at a confidence level of $95 \%$. If there were significant differences, then Duncan's test was performed to determine differences among treatments. Quantitative description analysis was used to explain the feasibilty of water quality in the rearing mediums for the life of mud crabs during the study.

\section{RESULTS AND DISCUSSION}

\section{Results}

\section{The content of calcium and magnesium}

The results of the analysis of the calcium content in the water, the crab and the feed (Table 1) showed that the highest value of the calcium content in the water at the end of the study was found in treatment A that was $649.86 \pm 2.63 \mathrm{mg} / \mathrm{L}$, and it was significantly different $(\mathrm{P}<0.05)$ to other treatments. On the other hand, the lowest value was found in treatment $B$ that was the addition of $30 \mathrm{mg} / \mathrm{L} \mathrm{Ca}$ and $30 \mathrm{mg} / \mathrm{L} \mathrm{Mg}$ every five days that resulted a value of $466.19 \pm 2.99$ $\mathrm{mg} / \mathrm{L}$. The highest amount of calcium contained in the crab was obtained in treatment $\mathrm{C}$ that was $49,244.52 \pm 206.08 \mathrm{mg} / \mathrm{L}$ and it was significantly different $(\mathrm{P}<0.05)$ to other treatments. On the other hand, the lowest value was obtained in treatment A that was a treatment without the addition of $\mathrm{Ca}$ and $\mathrm{Mg}$ that resulted a value of $16,154.43 \pm 134.27$ $\mathrm{mg} / \mathrm{L}$. The calcium content contained in the feed was $19,685.05 \pm 47.21 \mathrm{mg} / \mathrm{L}$.

Calcium and magnesium have a relationship in the formation of carapace in crustacea. Based on the results of the measurements of the magnesium content in the water, the crab and the feed (Table 2 ), it could be known that the highest value of $\mathrm{Mg}$ in the water was found in treatment $\mathrm{C}$ that was $1,022.99 \pm 8.60 \mathrm{mg} / \mathrm{L}$, and it was significantly different $(\mathrm{P}<0.05)$ to treatment $\mathrm{B}$ and $\mathrm{C}$. On the other hand, the lowest value of $\mathrm{Mg}$ in the water was found in treatment B that was $924.41 \pm 2.84 \mathrm{mg} / \mathrm{L}$. The highest amount of $\mathrm{Mg}$ in the crab at the end of the study was obtained in treatment $\mathrm{A}$ that was $6,800.67 \pm 200.38 \mathrm{mg} / \mathrm{L}$, and it was significantly different $(\mathrm{P}<0.05)$ to other treatments. The lowest amount of $\mathrm{Mg}$ contained in the crab was obtained in treatment $\mathrm{C}$ that was $3,251.12 \pm 10.41 \mathrm{mg} / \mathrm{L}$. The amount of $\mathrm{Mg}$ contained in the feed was $864.75 \pm 13.35 \mathrm{mg} / \mathrm{L}$.

\section{Water quality}

The addition of $\mathrm{Ca}$ and $\mathrm{Mg}$ to the rearing water influenced the content of $\mathrm{Ca}$ and $\mathrm{Mg}$ in the water and the crab, it also influenced the water quality of the rearing water. The most influenced water quality parameters because of the addition of $\mathrm{Ca}$ and $\mathrm{Mg}$ were water $\mathrm{pH}$ and alkalinity. The results of the measurements of water quality parameters were presented in Table 3 and Figure 2.

Based on the observations of water quality parameters during the rearing period, so data of temperature, dissolved oxygen, ammonia, nitrite, nitrate, salinity, and alkalinity were obtained (Table 3). The values of water quality indicated that all treatments had water quality ranges that could be tolerated by crabs to support their lives.

\section{Osmotic gradient}

The result of ANOVA indicated that treatments applied in this study significantly affected $(\mathrm{P}<0.05)$ to osmotic gradient of crab. The result of the measurement of osmotic gradient (Figure 3 ) during the rearing period gave an information that the lowest value was obtained in treatment $\mathrm{D}$ that was $0.263 \pm 0.008 \mathrm{mOsm} / \mathrm{L} \mathrm{H}_{2} \mathrm{O}$, while the highest value was obtained in treatment $\mathrm{A}$ that was $0.398 \pm 0.012 \mathrm{mOsm} / \mathrm{L} \mathrm{H}_{2} \mathrm{O}$. 
Table 1. The calcium content in the water, the crab, and the feed

\begin{tabular}{lcc}
\hline \multirow{2}{*}{ Treatments } & \multicolumn{2}{c}{ Calcium in the water $(\mathrm{mg} / \mathrm{L})$} \\
\cline { 2 - 3 } (A) Without any addition & $381.72 \pm 2.21$ & Final \\
(B) Every 5 days & $381.72 \pm 2.22$ & $649.86 \pm 2.63 \mathrm{a}$ \\
(C) Every 10 days & $381.72 \pm 2.23$ & $466.19 \pm 2.99 \mathrm{~d}$ \\
(D) Every 15 days & $381.72 \pm 2.24$ & $613.16 \pm 0.18 \mathrm{~b}$ \\
\multicolumn{2}{c}{ Treatments } & \multicolumn{2}{c}{ Calcium in the crab $(\mathrm{mg} / \mathrm{L})$} \\
\hline & Initial & $602.81 \pm 4.46 \mathrm{c}$ \\
\hline (A) Without any addition & $47,792.29 \pm 98.41$ & Final \\
(B) Every 5 days & $47,792.29 \pm 98.42$ & $16,154.43 \pm 134.27 \mathrm{~d}$ \\
(C) Every 10 days & $47,792.29 \pm 98.43$ & $44,611.03 \pm 151.93 \mathrm{~b}$ \\
(D) Every 15 days & $47,792.29 \pm 98.44$ & $49,244.52 \pm 206.08 \mathrm{a}$ \\
\hline
\end{tabular}

In the feed $(\mathrm{ppm})=19,685.05 \pm 47.21$

Note: Different letters after numbers indicate significant differences $(\mathrm{P}<0.05)$.

Table 2. The magnesium content in the water, the crab, and the feed

\begin{tabular}{lcc}
\hline \multirow{2}{*}{ Treatments } & \multicolumn{2}{c}{ Magnesium in the water $(\mathrm{mg} / \mathrm{L})$} \\
\cline { 2 - 3 } (A) Without any addition & Initial & Final \\
(B) Every 5 days & $903.35 \pm 6.37$ & $1,010.72 \pm 12.2 \mathrm{a}$ \\
(C) Every 10 days & $903.35 \pm 6.38$ & $958.51 \pm 2.73 \mathrm{~b}$ \\
(D) Every 15 days & $903.35 \pm 6.39$ & $1,022.99 \pm 8.61 \mathrm{a}$ \\
\multicolumn{1}{c}{ Treatments } & $903.35 \pm 6.40$ & $924.41 \pm 2.84 \mathrm{c}$ \\
\hline & \multicolumn{2}{c}{ Magnesium in the crab $(\mathrm{mg} / \mathrm{L})$} \\
\hline (A) Without any addition & $4,909.38 \pm 15.21$ & Final \\
(B) Every 5 days & $4,909.38 \pm 15.22$ & $6,800.67 \pm 200.38 \mathrm{a}$ \\
(C) Every 10 days & $4,909.38 \pm 15.23$ & $4,579.43 \pm 34.56 \mathrm{~b}$ \\
(D) Every 15 days & $4,909.38 \pm 15.24$ & $3,251.12 \pm 10.41 \mathrm{c}$ \\
\hline
\end{tabular}

In the feed $(\mathrm{mg} / \mathrm{L})=864.75 \pm 13.35$

Note: Different letters after numbers indicate significant differences $(\mathrm{P}<0.05)$.

\section{Oxygen consumption rate (OCR)}

The result of ANOVA indicated that treatments given in this study significantly affected $(\mathrm{P}<0.05)$ to oxygen consumption rate of mud crab. The lowest oxygen consumption rate was obtained in treatment $\mathrm{D}$ that was $0.0065 \pm 0.0004 \mathrm{mgO}_{2} / \mathrm{g} /$ hour, while the highest of that was found in treatment $\mathrm{A}$ that was $0.0113 \pm 0.0002 \mathrm{mgO}_{2} / \mathrm{g} /$ hour. The result of the measurement of oxygen consumption rate was presented in Figure 4.

Feed conversion ratio and daily growth rate (DGR)

The result of ANOVA indicated that treatments in this study significantly affected $(\mathrm{P}<0.05)$ to feed conversion of crab. The result of the calculation of feed conversion ratio (Figure 5) during the rearing period revealed an information that the lowest value was obtained in treatment $C$ that was $8.18 \pm 0.18$, while the highest value was obtained in treatment A that was $10.65 \pm 0.85$.

The result of ANOVA indicated that treatments in this study significantly affected $(\mathrm{P}<0.05)$ to daily growth rate of crab. The result of the calculation of daily growth rate (Figure 6) during the rearing period demonstrated an information that the lowest value was obtained in treatment A that was $1.116 \pm 0.04 \% /$ day, while the highest value was obtained in treatment $\mathrm{C}$ that was $1.733 \pm 0.06 \% /$ day. 
Table 3 . The water quality ranges during the rearing period

\begin{tabular}{lcccc}
\hline \multirow{2}{*}{ Composition } & \multicolumn{4}{c}{ Treatments } \\
\cline { 2 - 5 } & $\begin{array}{c}\text { A) } \begin{array}{c}\text { Without } \\
\text { addition }\end{array} \\
\text { Temperature }\left({ }^{\circ} \mathrm{C}\right)\end{array}$ & $\begin{array}{l}\text { (B) Every } 5 \text { days } \\
\text { (C) Every 10 days }\end{array}$ & (D) Every 15 days \\
Dissolved oxygen $(\mathrm{mg} / \mathrm{L})$ & $6.56 \pm 0.09$ & $6.73 \pm 0.12$ & $6.66 \pm 0.09$ & $6.64 \pm 0.07$ \\
Ammonia $(\mathrm{mg} / \mathrm{L})$ & $0.0343 \pm 0.003$ & $0.591 \pm 0.59$ & $0.315 \pm 0.06$ & $0.213 \pm 0.02$ \\
Nitrite $(\mathrm{mg} / \mathrm{L})$ & $1.138 \pm 0.034$ & $0.595 \pm 0.036$ & $0.651 \pm 0.039$ & $0.632 \pm 0.039$ \\
Nitrate $(\mathrm{mg} / \mathrm{L})$ & $0.382 \pm 0.018$ & $0.339 \pm 0.019$ & $0.343 \pm 0.023$ & $0.416 \pm 0.018$ \\
Salinity $(\mathrm{g} / \mathrm{L})$ & $23.25 \pm 0.11$ & $22.86 \pm 0.22$ & $22.72 \pm 0.12$ & $23.49 \pm 0.09$ \\
Alkalinity $(\mathrm{mg} / \mathrm{L} \mathrm{CaCO}$ ) & $108.69 \pm 14.14$ & $143.19 \pm 17.93$ & $139.74 \pm 20.92$ & $169.07 \pm 14.94$ \\
\hline
\end{tabular}

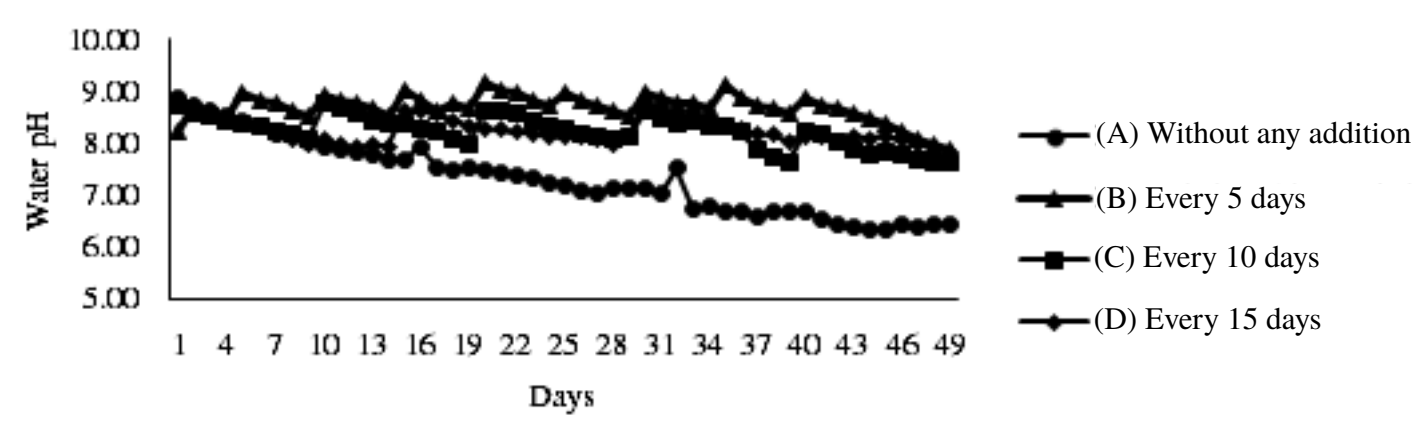

Figure 2. The water $\mathrm{pH}$ values during the rearing period

The number of molting, survival, and total biomass

Based on the result of ANOVA, it could be known that treatments applied in this study significantly affected $(\mathrm{P}<0.05)$ to the number of molting of crab. The result of the calculation of the number of molting (Figure 7) during the rearing period demonstrated that the highest value was obtained in treatment $D$ that was $18.67 \pm 1.15$ shells while the lowest value was obtained in treatment A that was $10 \pm 1.73$ shells.

Based on the result of ANOVA, it could be known that treatments given in this study significantly affected $(\mathrm{P}<0.05)$ to survival of crab. The result of the calculation of survival (Figure 8) during the rearing period showed that the highest value was obtained in treatment $\mathrm{D}$ that was $86.67 \pm 5.77 \%$, while the lowest value was obtained in treatment A that was $40 \pm 5 \%$.

Based on the result of ANOVA, it could be known that treatments in this study significantly affected $(\mathrm{P}<0.05)$ to total biomass. The result of the calculation of total biomass (Figure 9) during the rearing period indicated that the highest value was obtained in treatment $D$ that was $1,054.41 \pm 73.54 \mathrm{~g}$, while the lowest value was obtained in treatment A that was 376.99 $\pm 86.16 \mathrm{~g}$.

\section{Discussion}

The calcium content in the water at the beginning and the end of the rearing period experienced an increase in its solubility. Treatments through the addition of calcium and magnesium demonstrated the increasing of the calcium content. This was caused by the addition of calcium to rearing mediums. In the treatment without the addition of calcium and magnesium, the calcium content increased because crabs took magnesium to replace calcium in their bodies. This treatment also had the lower calcium content in the body than that on other treatments. This was indicated by the calcium content at the end of the rearing period (Table 1) and the magnesium content in the crab (Table 2). According to Bogart et al. (2016) crab needs calcium for the formation of carapace but its absorption is impaired with a low amount of free calcium contained in the medium. Calcium in sea water binds to $\mathrm{CO}_{2}$ forming $\mathrm{CaCO}_{3}$. According to Calhoun and $\mathrm{Zou}$ (2016) calcium and magnesium are the largest components of exoskeleton (carapace) that are absorbed before molting.

The most influenced water quality parameters because of the addition of $\mathrm{Ca}$ and $\mathrm{Mg}$ were water $\mathrm{pH}$ and alkalinity. Alkalinity values among 


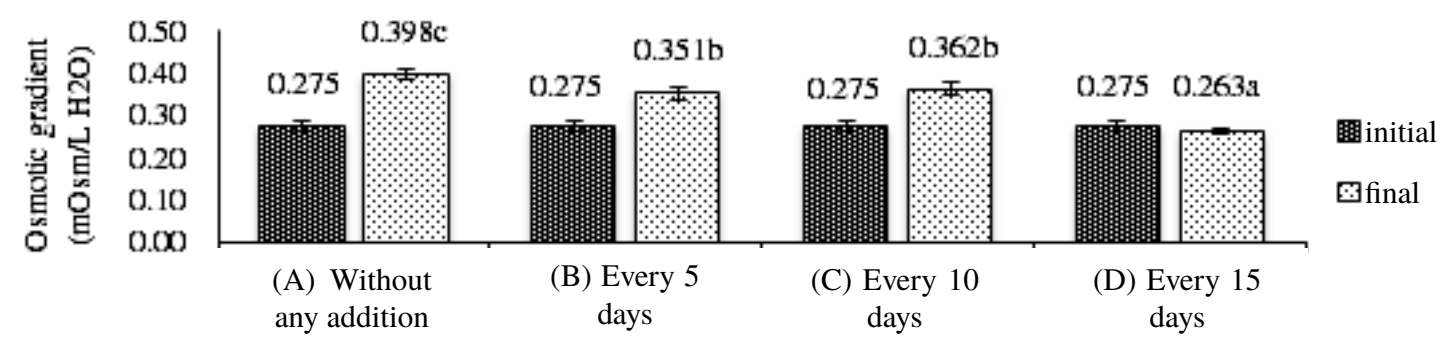

Treatments

Figure 3. Osmotic gradient of crab. Different letters on bars indicate significant differences at a significance level of $5 \%$ (Duncan's test).

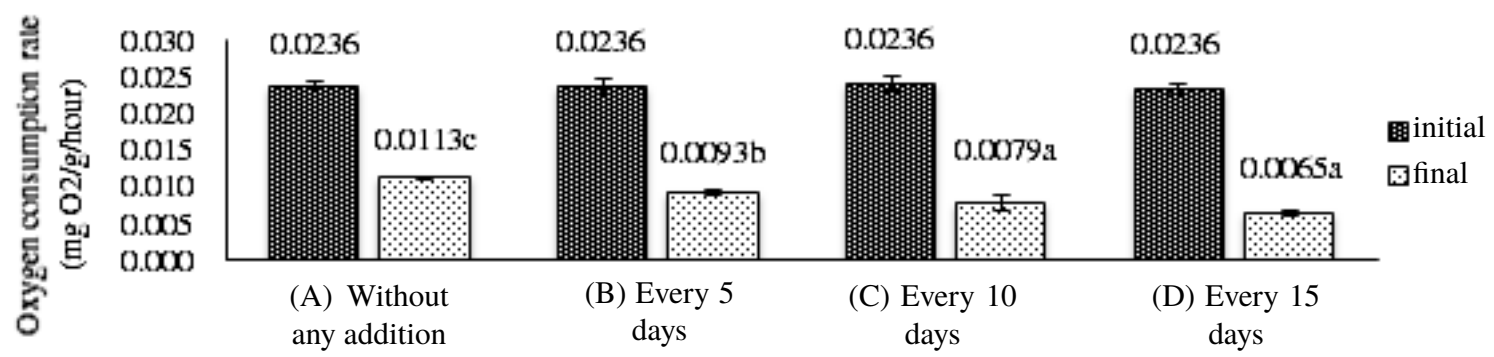

Treatments

Figure 4. Oxygen consumption rate of mud crab. Different letters on bars indicate siginificant differences at a significance level of 5\% (Duncan's test).

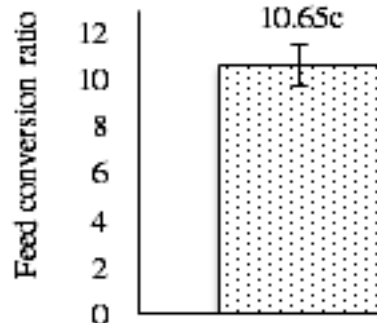

(A) Without any addition

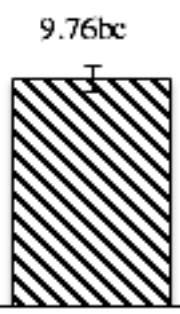

(B) Every 5 days
$8.18 \mathrm{a}$

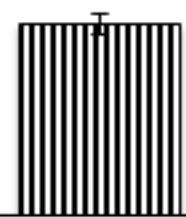

(C) Every 10 days 9.10ab

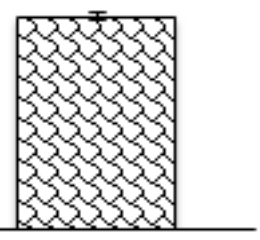

(D) Every 15 days

\section{Treatments}

Figure 5. Feed conversion during the rearing period of mud crab. Different letters on bars indicate significant differences at a significance level of 5\% (Duncan's test).

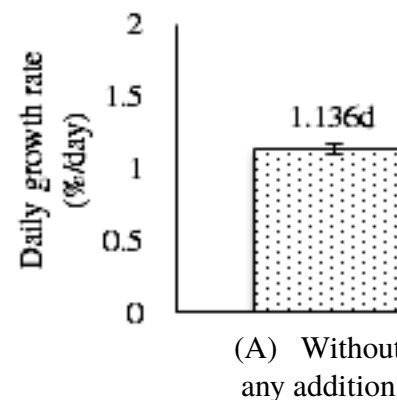

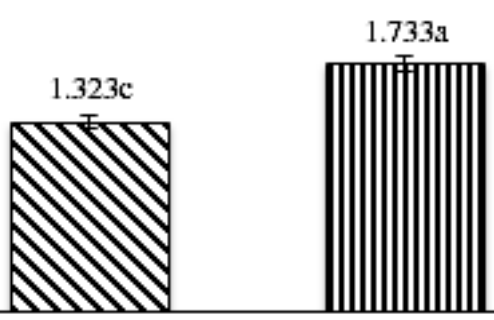

(B) Every 5 days
(C) Every 10 days
$1,612 \mathrm{~b}$
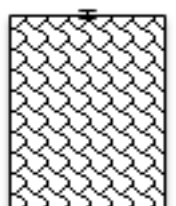

$\sin 2 \infty \lambda$

(D) Every 15

days

\section{Treatments}

Figure 6. Daily growth rate of mud crab. Different letters on bars indicate significant differences at a significance level of 5\% (Duncan's test). 


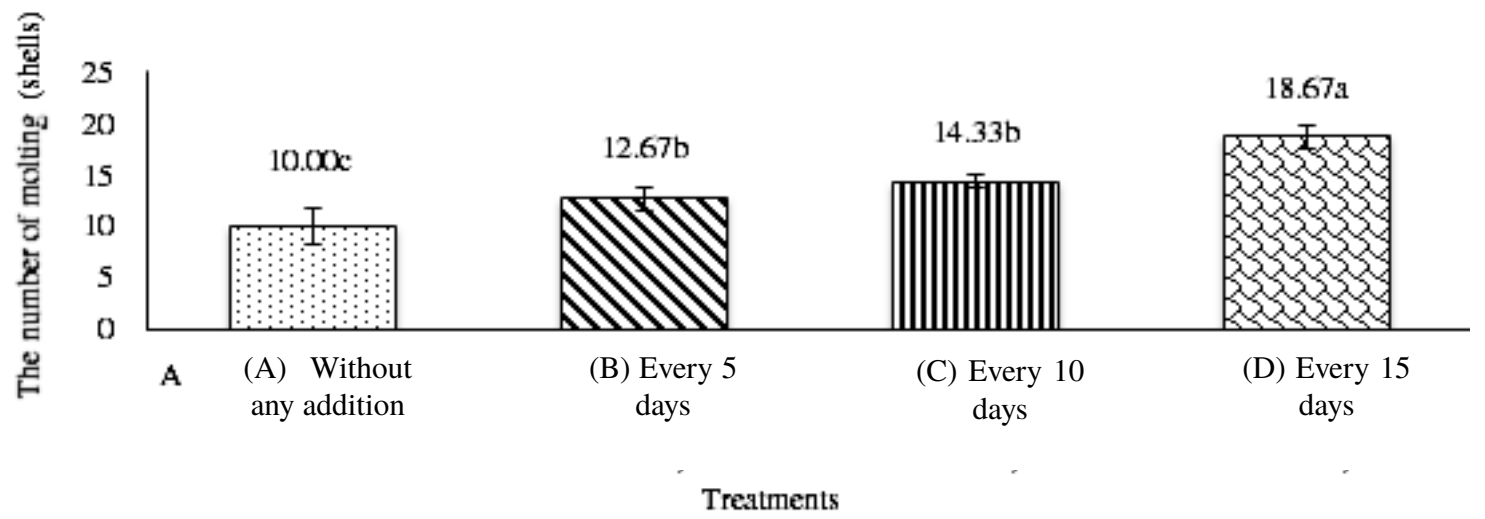

Figure 7. The number of molting of mud crab. Different letters on bars indicate significant differences at a significance level of 5\% (Duncan's test).

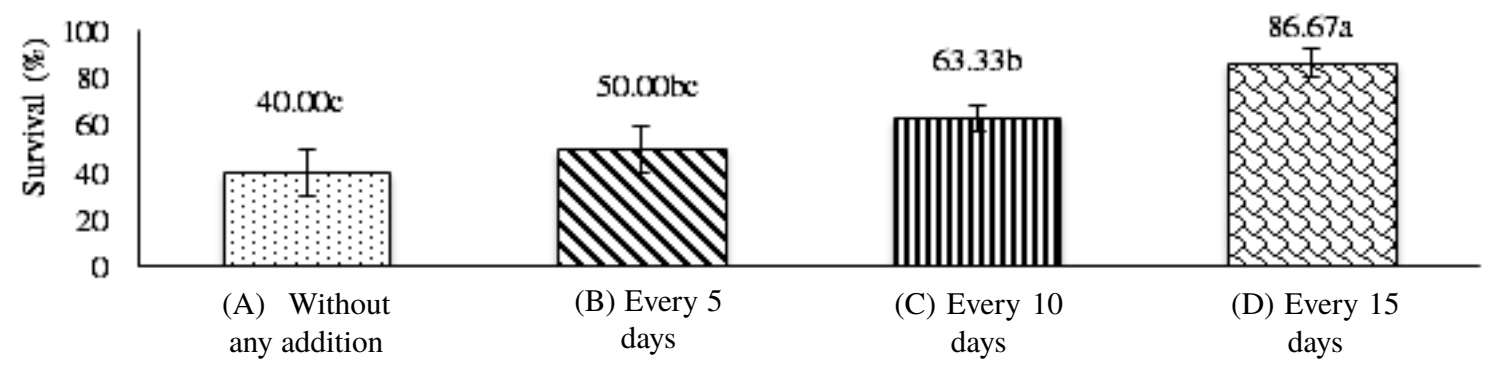

Treatments

Figure 8. Survival of mud crab. Different letters on bars indicate significant differences at a significance level of $5 \%$ (Duncan's test).

treatments indicated that treatment $\mathrm{A}$ (without the addition of $\mathrm{Ca}$ and $\mathrm{Mg}$ ) had the lowest value compared to other treatments. This occurred because the composer of alkalinity was $\mathrm{CaCO}_{3}$. According to Bogart et al. (2016) alkalinity is composed by many minerals that can influence alkalinity and hardness. So that when calcium is absorbed by crabs, it causes a decrease in alkalinity. On the other hand, treatments with the addition of $\mathrm{Ca}$ and $\mathrm{Mg}(\mathrm{B}, \mathrm{C}$, and D) had stable alkalinity values.

In addition to alkalinity, $\mathrm{pH}$ also becomes the most influenced parameter because of the addition of $\mathrm{Ca}$ and $\mathrm{Mg}$. The $\mathrm{pH}$ values during the rearing period showed that $\mathrm{pH}$ in treatment $\mathrm{A}$ decreased compared to other treatments. On the other hand, treatments with the addition of $\mathrm{Ca}$ and $\mathrm{Mg}$ had dynamics that are almost same among treatments (Figure 1). According to Glandon and Miller (2016) the molting process in crabs can cause a drop in water $\mathrm{pH}$. Low $\mathrm{pH}$ can be risen up by the addition of $\mathrm{Ca}$ and $\mathrm{Mg}$.

Osmotic gradient in treatment $\mathrm{D}$ (the addition of $30 \mathrm{mg} / \mathrm{L} \mathrm{Ca}$ and $30 \mathrm{mg} / \mathrm{L} \mathrm{Mg}$ every 15 days) showed that in this treatment, body osmotic fluid with medium osmotic fluid tended on a balanced condition or nearly isoosmotic. Thus, the physiological function of crabs would run normally because the energy used for osmoregulation is not too high. In this treatment, the working process of osmoregulation caused by hyperosmotic conditions in crabs to the environment will be reduced by the addition of $30 \mathrm{mg} / \mathrm{L} \mathrm{Ca}$ and $\mathrm{Mg}$ every 15 days. Therefore, body osmotic fluid with medium osmotic fluid tended to be more isoosmotic and caused osmotic gradient value in this treatment becoming lower than that on other treatments. Calcium plays a role to keep the body condition of organisms against changes in osmotic pressure (Sakamoto et al. 2013). High osmotic gradient values in other treatments indicated that body osmotic fluid with medium osmotic fluid tended to be hyperosmotic or hypoosmotic. This caused a high amount of energy required for osmoregulation to prevent the loss of minerals in the body. According to Hong et al. (2013) osmolarity can influence the use of energy by organisms in the rearing process. Isoosmotic condition is the optimum condition for the growth of crabs. 


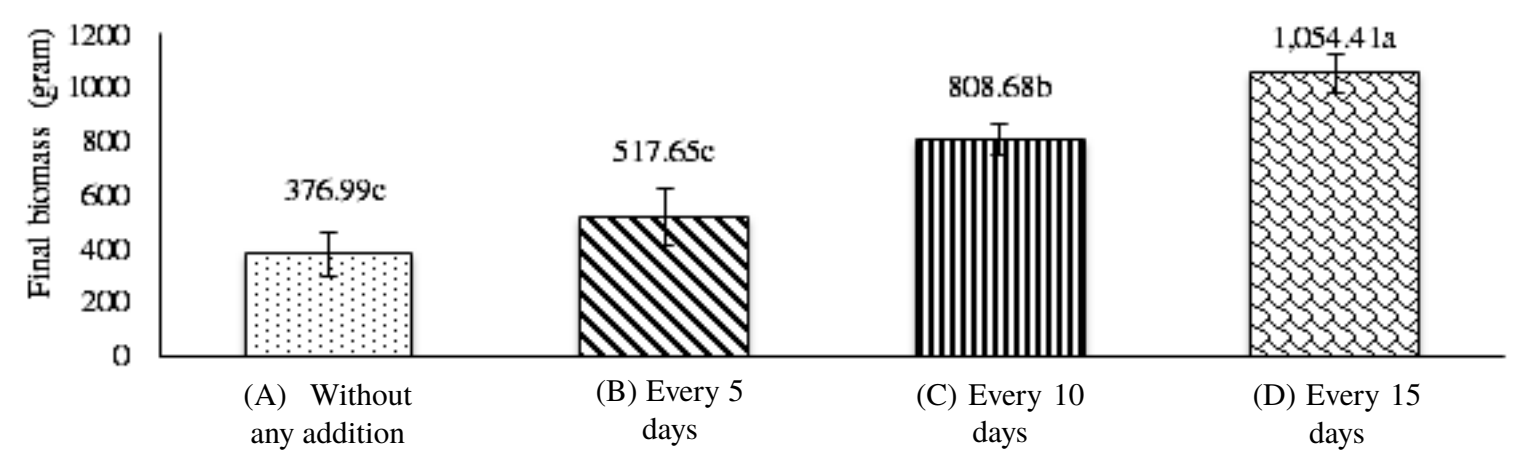

Treatments

Figure 9. Final biomass of mud crab. Different letters on bars indicated significant differences at a significance level of $5 \%$ (Duncan's test).

The lowest oxygen consumption rate was obtained in treatment $\mathrm{D}$ (the addition of 30 $\mathrm{mg} / \mathrm{L} \mathrm{Ca}$ and $30 \mathrm{mg} / \mathrm{L} \mathrm{Mg}$ every 15 days) that was $0.0065 \pm 0.004 \mathrm{mgO}_{2} / \mathrm{g} /$ hour. A low oxygen consumption rate in this treatment closely related to the lowest osmotic gradient that was also obtained in the same treatment. When crabs require energy for osmoregulation process, crabs will utilize energy sources existing in their bodies that are glucose and oxygen for oxidation. Thus, a low value in osmotic gradient will save more energy, as well as the consumption of oxygen that is used as a material for the oxidation of energy source materials derived from the consumed feed. The highest oxygen consumption rate in the treatment without the addition of $\mathrm{Ca}$ and $\mathrm{Mg}$ was in accordance with the highest osmotic gradient that was also obtained in this treatment, so crabs will perform osmoregulation process to maintain their homeostasis states. According to Li et al. (2007) the fish will perform more moving and swimming activities, so it will have a high respiratory activity. This condition was expressed by the highest oxygen consumption rate in the treatment without the addition of $\mathrm{Ca}$ and $\mathrm{Mg}$ than that on other treatments.

Oxygen consumption rate can be used as a parameter to determine the metabolism rate of aquatic organisms. Oxygen consumption rate influences the use of energy when the metabolism process occurs in the crab body (Silikavuopio \& James, 2015). The lower the oxygen consumption rate the less energy is used for metabolism and energy is expected to be available more for the growth.

Feed conversion is a ratio between weight gain of crabs and the amount of the consumed feed. The results of this study showed that treatment $\mathrm{C}$ and D had insignificant different $(\mathrm{P}>0.05)$ feed conversion values. This led to insignificant growth rates. A high growth is characterized by a faster molting process. The transfer process of calcium and magnesium from hemolymph to carapace is performed through active transport mechanism that requires an energy. Transfer of $\mathrm{Ca}$ and $\mathrm{Mg}$ to carapace that runs faster is characterized by a high deposition rate of calcium and magnesium in carapace that also requires a high amount of energy. This large energy requirement is obtained from the consumed feed, as Tavabe et al. (2013) stated that a deficiency of $\mathrm{Ca}$ ion in crab could inhibit its growth that led to an increase in feed conversion.

The highest feed conversion was on treatment A that was $10.65 \pm 0.85$ (Figure 4). On the other hand, the lowest growth rate was $1.136 \pm 0.04 \%$. A high feed conversion indicated that there was a high amount of energy lost for osmoregulation process on the reared crabs. If the environmental condition is on optimum condition that is characterized by low osmotic gradient and oxygen consumption, so the energy obtained from the feed will be utilized maximally for the growth. Hypreosmotic and hypoosmotic conditions cause the feed given becoming not used for the growth of crabs. But the energy will be spent to equalize osmotic conditions both outside and inside the body. Tavabe et al. (2015) stated that $\mathrm{Ca}$ ion when interacted with magnesium could increase the growth of crustacea. According to Ling et al. (2013), calcium plays a role in the formation of body tissues especially bones and exoskeleton.

Frequencies in the additon of $\mathrm{Ca}$ and $\mathrm{Mg}$ resulted differences in the number of molting in mud crabs. Treatment D had the highest number of molting (18.67 \pm 1.15 shells) and it was sig- 
nificantly different $(\mathrm{P}<0.05)$ to other treatments. Molting is the shell replacement process in crustacean group. The $\mathrm{Ca}^{2+}$ plays a role as a trigger in ecdysteroidogenesis or ecdysteroid synthesis (Teruaki et al., 2009). The $\mathrm{Ca}^{2+}$ also plays a role in gastrolisation process that is the absorption of $\mathrm{Ca}^{2+}$ contained in crustacean body for the hardening process of the new shell after sucessfully removing the old shell. This occurs when the crab flesh size becomes larger while exoskeleton does not become larger because exoskeleton is a rigid part, so to adapt in that condition this animal will remove the old exoskeleton and forms the new exoskeleton with an aid derived from calcium (Soundarapandian et al., 2013). A young crab with a high growth rate has a molting frequency that is more often than an adult crab. Molting is also influenced by sex, physiological conditions, temperature, water chemical factors, quality and quantity of food. Molting cycle is influenced by hormonal system, organism and feed, it is also influenced by environmental factors of the water (Zaidy et al., 2008).

\section{CONCLUSION}

The optimum frequency of the addition of calcium and magnesium in recirculation system to increase the production and the formation of the mud crab shell is every 15 days with a concentration of $30 \mathrm{mg} / \mathrm{L}$.

\section{REFERENCES}

APHA. 2012. Standard methods for the examination of water and wastewater. Washington DC [US]: American Public Health Association.

Bogart SJ, Samuel W, Dylan S, Cindy M, Greg GP. 2016. Rapid changes in water hardness and alkalinity: calcite formation is lethal to Daphnia magna. Journal Science of the Total Environment 559: 182-191.

Calhoun S, Zou E. 2016. Epidermal carbonic anhydrase activity and exoskeletal metal content during the molting cycle of the blue crab Collinectus sopidus. Journal Experimental Zoology 325A: 200-208.

Fabritius HO, Eva SK, Keerthika B, Sabine H, Katja H, Dierk R. 2012. Correlation of structure, composition and local mechanical properties in the dorsal carapace of the edible crab Cancer pagurus. Journal Zeitschrift fur Kristallographie 227: 766-776.
Glandon HL, Miller TJ. 2016. No effect of high $\mathrm{CO}_{2}$ on juvenile blue crab, Callinectus sapidus, growth and consumption despite positive responses to concurrent warming. ICES Journal of Marine Science 171: 1-9.

Granado M, Baptista BB, Farah LS, Leite VP, Zanotto FP. 2010. Calcium transport and homeostatis in gill cells of a freshwater crab Dilocarcinus pagei. Journal of Comparative Physiology 180: 313-321.

Hong Y, Xiaozhen Y, Yongxu C, Pan L, Jinbiao Z, Meng L, Cheng S, Zhigang Y, Chun W. 2013. Effects of $\mathrm{pH}$, temperature, and osmolarity on the morphology and survival rate of primary hemocyte cultures from the Mitten Crab, Erioheir sinensis. Journal In Vitro Cellular Development Biology-Animal 49: 716-727.

Li E, Chen C, Zeng X, Chen N, Yu Q, Lai, Qin IG. 2007. Growth, body composition, respiration and ambient ammonia nitrogen tolerance of the juvenile white shrimp Litopenaeus vannamei. Aquaculture 265: 385-390.

Ling HY, Ching YK, Shiiau SY. 2013. Estimation of dieteary magnesium requirement of juvenile tilapia Oreochromis niloticus $x$ Oreochromis aureus, reared in freshwater and seawater. Aquaculture 383: 47-51.

Marzuki A, Yushinta F, Muhammad R, Haslina. 2013. Analisis kandungan kalsium (Ca) dan besi (Fe) pada kepiting bakau Scylla olivacea cangkang keras dan cangkang lunak dengan metode spektrofotometer serapan atom. Majalah Farmasi dan Farmakologi 1 17: 31-60.

[NRC] National Research Council. 1977. Nutrient requirements of warm-water fishes. Washington DC (US): National Academy of sciences.

Sakamoto T, Satoshi O, Yuda N, Waichirou G, Hideya T. 2013. Osmolality and ionic status of hemolymph and branchial $\mathrm{Na}^{+} / \mathrm{K}^{+}$-ATPase in adult mitten crab during seawater adaptation. Herbert open access journals 874: 2-15.

Soundarapandian P, Varadharajan D, Sivasubramanian C. 2013. Mineral composition of edible Crab, Charybdis Natator Herbst (Crustacea: Decapoda). Journal Bioanalysis and Biomedicine 54: 99-101

Shannon MA, Paul WB, Menachem E, John GG, Benito JM, Anne MM. 2008. Science and technology for water purificarion in the coming decades. Nature 452: 301-310.

Silikavuopio SI, James P. 2015. Effects of temperature on feed intake, growth and 
oxygen consumption in adult male king crab Paralithodes camtschaticus held in capativity and manufactured diets. Aquaculture Research 46: 602-608.

Tavabe KR, Gholamreza R, Michael P, Harry D. 2013. Effects of different and magnesium concentrations separately and in combination on Macrobrachium rosenbergii (de Man) larvaculture. Aquaculture 412: 160-166.

Tavabe KR, Gholamreza R, Mohammad MS, Shadab H, Michael F, Harry D. 2015. Effects of water hardness and calcium: magnesium ratios on reproductive performance and offspring quality of Macrobrachium rosenbergii. Journal World Aquaculture Society 46: 519-530.

Teruaki N, Chi-Ying L, Robert DW. 2009.
Crustacean molt-inhibiting: Structure, function, and cellular mode of action. Comparative Biochemistry and Physiology 152: 139-148.

Timmons MB, Losordo TM. 1994. Aquaculture Water Reuse System: Engineering Design and Management. Amsterdam [NL]: Elsevier Science.

Zaidy AB, Ridwan A, Bambang K, Kardiyo P, Wasmen M. 2008. Utilization of Calcium in Aquatic Environment for Molting Process and Its consequence on Giant Freshwater Prawn Growth Rate (Macrobrachium rosenbergii de Man. Jurnal Ilmu-ilmu Perairan dan Perikanan Indonesia 15: 117-125. 